\title{
Kartel Angkutan Kontainer Pelabuhan Belawan Tahun 2011 Dan 2012
}

\author{
Dhiyan Utama \\ Program Pasca Sarjana Fakultas Hukum Universitas Islam Indonesia \\ Jln. Cik Di Tiro No. 1, Yogyakarta, 55223 \\ dhiyan.utama@gmail.com
}

\begin{abstract}
The rule of evidence in the existence of a price fixing agreement according to Article 5 of Law No. 5 of 1999 on Monopoly and Unfair Business Competition refers more to material evidence without prejudice to written evidence as formal evidence. Therefore, this study aims to analyze: first, what are the evidences that can be used by the Business Competition Supervision Commission (KPPU) in examining alleged cartel violations; and second, what is the rule of evidence which is carried out by KPPU in examining alleged cartel violations. This is a normative research with statutory approach and case studies. The results conclude that the actions of the business actors as reported parties tend to be the actions that are prohibited by law. Meanwhile, the KPPU Decision No. 06/KPPU-I/2013 on the Cartel Case of the Belawan Port Container Transport Tariff in Indonesia, in the process of proving it, applies indirect evidence as a guide to complete the evidence in the Commission Council session. The basis for the consideration of the District Court and Supreme Court is the belief that indirect evidence is not regulated in Indonesian procedural law. However, in its development, in 2011 the Supreme Court began to acknowledge indirect evidence through the Supreme Court Decision on rigging tender case No. 906K/Pdt.Sus/2010.
\end{abstract}

Key Words: Cartel; indirect evidence; KPPU

\begin{abstract}
Abstrak
Konsep pembuktian adanya perjanjian penetapan harga menurut Pasal 5 UU No. 5 Tahun 1999 tentang Monopoli dan Persaingan Usaha Tidak Sehat lebih merujuk kepada pembuktian secara materiil tanpa mengesampingkan bukti tertulis sebagai pembuktian formal. Maka dari itu penelitian ini bertujuan untuk menganalisa: pertama, apa sajakah alat bukti yang dapat digunakan oleh Komisi Pengawasan Persaingan Usaha (KPPU) dalam pemeriksaan dugaan pelanggaran kartel; dan kedua, bagaimana cara pembuktian yang dilakukan oleh KPPU dalam pemeriksaan dugaan pelanggaran kartel. Penelitian ini bersifat normatif dengan pendekatan perundang-undangan dan studi kasus. Hasil penelitian menyimpulkan, bahwa perbuatan pelaku usaha sebagai terlapor memiliki tendensi ke arah perbuatan yang dilarang oleh undang-undang. Sedangkan Putusan KPPU No.06/KPPU-1/2013 tentang Kasus Kartel Tarif Angkutan Kontainer Pelabuhan Belawan di Indonesia dalam proses pembuktiannya menggunakan alat bukti tidak langsung sebagai petunjuk untuk menyempurnakan pembuktian dalam sidang Majelis Komisi. Dasar pertimbangan Pengadilan Negeri dan Mahkamah Agung ini adalah keyakinan bahwa alat bukti tidak langsung tidak diatur dalam hukum acara di Indonesia. Namun dalam perkembangannya, pada tahun 2011 Mahkamah Agung mulai mengakui alat bukti tidak langsung melalui Putusan Mahkamah Agung mengenai kasus persekongkolan tender No. 906K/Pdt.Sus/2010.
\end{abstract}

Kata-kata Kunci: Alat bukti tidak langsung; kartel; KPPU 


\section{Pendahuluan}

Dalam aktivitas bisnis dapat dipastikan terjadi persaingan (competition) di antara pelaku usaha. Pelaku usaha akan berusaha menciptakan, mengemas, serta memasarkan produk yang dimiliki baik barang/jasa sebaik mungkin agar diminati dan dibeli oleh konsumen. Persaingan dalam usaha dapat berimplikasi positif, sebaliknya dapat menjadi negative jika dijalankan dengan perilaku negatif dan sistem ekonomi yang menyebabkan tidak kompetitif. ${ }^{1}$

Larangan praktek monopoli dan persaingan usaha tidak sehat diatur di dalam Undang-Undang No. 5 Tahun 1999. Salah satu jenis perjanjian yang dilarang dalam Undang-Undang No. 5 Tahun 1999 adalah kartel. Larangan kartel secara eksplisit merujuk pada Pasal 11 Undang-Undang No. 5 Tahun 1999. Secara umum kartil diartikan sebagai perjanjian di antara pelaku usaha yang bertujuan menghambat persaingan dengan cara menaikkan harga dan keuntungan. Adapun yang mendorong pendirian kartel adalah persaingan ketat di pasar sejenis. Untuk menghindari persaingan fatal ini, anggota kartel setuju menentukan harga bersama, mengatur produksi, bahkan menentukan secara bersama potongan harga, promosi, dan syarat-syarat penjualan lain. ${ }^{2}$

Kartel disebut juga sebagai "syndicate", yaitu suatu kesepakatan (tertulis) antara beberapa perusahaan produsen dan lain-lain yang sejenis untuk mengatur dan mengendalikan berbagai hal, seperti harga, wilayah pemasaran, dengan tujuan menekan persaingan dan meraih keuntungan. ${ }^{3}$ Praktek kartel merupakan salah satu strategi yang diterapkan di antara pelaku usaha untuk dapat memengaruhi harga dengan mengatur jumlah produksi mereka.

Kartel dapat terjadi dalam beberapa bentuk, sebagai contoh para pemasok mengatur agen penjual tunggal yang membeli semua output mereka dengan harga yang disetujui dan mengadakan pengaturan dalam memasarkan produk tersebut secara terkoordinasi. Bentuk lainnya adalah para pemasok melakukan perjanjian dengan menentukan harga jual yang sama terhadap produk mereka, sehingga menghilangkan persaingan harga, tetapi bersaing dalam merebut pangsa pasar dengan strategi pembedaan produk, contoh lain adalah ditetapkannya kuota bongkar muat peti kemas oleh beberapa pelaku usaha yang mana tujuan dari pelaku usaha tersebut untuk mencegah terjadinya perang harga,akan tetapi yang dilakukan oleh beberapa pelaku usaha tersebut telah meniadakan persaingan usaha antara anggota kartel. Praktek kartel dapat

\footnotetext{
${ }^{1}$ Mustafa Kemal Rokan, Hukum Persaingan Usaha, RajaGrafindo Persada, Jakarta, 2012, hlm. 8.

${ }^{2}$ Anna Maria Tri Anggraini, "Penggunaan Bukti Ekonomi dalam Kartel Berdasarkan Hukum Persaingan Usaha”, Jurnal Hukum PRIORIS, Vol.3 No.3, 2013, hlm. 3.

${ }^{3}$ Hasim Purba, "Tinjauan terhadap Holding Company, Trust, Cartel dan Concern”, http:// repository.usu.ac.id/handle/123456789/1507, diakses tanggal 22 Januari 2016.
} 
berjalan sukses apabila pelaku usaha yang terlibat di dalam perjanjian tersebut haruslah mayoritas dari pelaku usaha yang berkecimpung dalam pasar tersebut. ${ }^{4}$

Seperti yang terjadi pada bisnis angkutan kontainer di pelabuhan Belawan pada 2011 sampai 2012. Majelis Komisi Pengawas Persaingan Usaha (KPPU) dalam Perkara No. 06/KPPU-I/2013 tentang Dugaan Pelanggaran UndangUndang No. 5 Tahun 1999 memutuskan sejumlah pengusaha angkutan barang melakukan praktek kartel terkait penentuan tarif angkutan kontainer ukuran 20 kaki, 40 kaki dan $2 \times 20$ kaki di 12 rute dari dan menuju Pelabuhan Belawan pada 2011 dan 2012. KPPU mendalami perkara tersebut dengan berdasarkan bukti bahwa adanya perjanjian yang ditandatangani oleh satu atau lebih pelaku usaha, yang saling mengikatkan diri terhadap satu atau lebih pelaku usaha lain, untuk menetapkan tarif angkutan kontainer di 12 rute dari dan menuju pelabuhan Belawan pada 2011 dan 2012. Adapun para pihak yang menjadi terlapor dalam perkara ini adalah adalah CV Belawan Indah selaku Terlapor I, PT Mitra Jaya Bahari selaku Terlapor II, CV Jaya Abadi Trans selaku Terlapor III, CV Idan selaku Terlapor IV, PT Benua Samudera Logistik selaku Terlapor V, PT Transporindo Agung Sejahtera selaku Terlapor VI, CV Wahana Multi Karsa selaku Terlapor VII, PT Samudera Perdana selaku terlapor VIII, Koperasi Pegawai Republik Indonesia "Baruna Barat" Belawan selaku Terlapor IX, PT Berkat Nugraha Sinar Lestari selaku Terlapor X, PT Tunas Jaya Utama selaku Terlapor XI, Fa. Multatuli Bhakti selaku Terlapor XII, PT Lintas Samudera Jaya selaku Terlapor XIII, Dewan Pimpinan Unit ORGANDA Angkutan Barang Pelabuhan Belawan selaku Terlapor XIV, Dewan Pengurus Wilayah Sumatera Utara Gabungan Forwarder, Penyedia Jasa Logistik \&Ekspedisi Seluruh Indonesia (GAPEKSI) selaku Terlapor XV. Menurut KPPU bahwa tindakan yang dilakukan oleh para terlapor tersebut merupakan tindakan yang menghambat persaingan usaha yang sehat atau dapat menghilangkan persaingan dan merugikan konsumen, sehingga atas perbuatan dari terlapor tersebut telah meniadakan alternatif pilihan tarif baik yang akan ditawarkan oleh penyedia jasa sesuai dengan variasi kualitas pelayanannya maupun yang akan dipilih langsung oleh konsumen sesuai dengan kebutuhannya. Karena tindakan tersebut terlapor I sampai terlapor XIII masing-masing dihukum dengan membayar denda mulai dari Rp. 22.000.000,00 sampai Rp. 463.020.000,00 dan KPPU merekomendasikan

${ }^{4}$ Andi Fahmi Lubis dkk.,Hukum Persaingan Usaha: Antara Teks \& Konteks, KPPU Republik Indonesia, Jakarta, 2009, hlm. 107. 
kepada Organisasi Angkutan Darat (ORGANDA) Sumatera Utara agar melakukan pembinaan kepada DPU Organda Belawan Sumatera Utara ${ }^{5}$.

Dalam proses pemeriksaannya tersebut, KPPU memerlukan bukti-bukti bahwa pelaku usaha yang bersangkutan melanggar Undang-Undang No. 5 Tahun 1999 dan peraturan pelaksanaanya. Adapun alat-alat bukti yang digunakan oleh KPPU berbeda dengan alat-alat bukti yang digunakan hukum acara perdata, tetapi mirip dengan alat-alat bukti yang tercantum dalam KUHAP.

Pada ketentuan Pasal 42 Undang-Undang No. 5 Tahun 1999 disebutkan alatalat bukti yang digunakan dalam pemeriksaan KPPU, yaitu berupa : a. keterangan saksi; b. keterangan ahli; c. surat dan atau dokumen; d. Petunjuk; dan e. Keterangan pelaku usaha

Ketentuan mengenai alat-alat bukti dalam pemeriksaan KPPU, dipertegas kembali dalam Pasal 72 ayat (1) Peraturan Komisi Pengawas Persaingan Usaha Nomor 1 Tahun 2010, yang menentukan sebagai berikut :

"Dalam menilai terjadi atau tidaknya pelanggaran, Majelis Komisi menggunakan alat-alat bukti berupa :

a. Keterangan saksi

b. Keterangan ahli

c. Surat dan atau dokumen

d. Petunjuk

e. Keterangan terlapor"

Dengan adanya Putusan KPPU No. 06/KPPU-I/2013 tentang Dugaan Pelanggaran Undang-Undang No. 5 Tahun 1999, di atas penulis akan memaparkan tentang apa saja alat bukti yang digunakan oleh KPPU untuk membuktikan bahwa para terlapor tersebut terbukti telah melakukan kartel dan bagaimna cara pembuktian yang dilakukan oleh KPPU agar tindakan terlapor tersebut betul melakukan kartel.

\section{Rumusan Masalah}

Berdasarkan latar belakang yang telah dijabarkan di atas, rumusan masalah yang akan dibahas dalam penelitian ini adalah: Pertama, apa saja alat bukti yang dapat digunakan oleh KPPU dalam pemeriksaan dugaan pelanggaran kartel? Da Kedua, bagaimana cara pembuktian yang dilakukan oleh KPPU dalam pemeriksaan dugaan pelanggaran kartel?

5“Kartel Pengusaha Angkutan di Belawan", http://medan.kppu.go.id/2014/11/kartel-pengusahaangkutan-di-belawan/, diakses tanggal 28 Januari 2016. 


\section{Tujuan Penelitian}

Atas dasar permasalahan yang telah dikemukakan di atas, tujuan yang hendak dicapai dari karya tulis ini adalah: Pertama, untuk menganalisis apa saja alat bukti yang dapat digunakan dalam rangka membuktikan telah terjadinya kartel; dan Kedua, untuk menganalisis bagaimanakah cara pembuktian yang dilakukan oleh KPPU dalam pemeriksaan dugaan pelanggaran kartel.

\section{Metode Penelitian}

Penelitian pada dasarnya merupakan suatu upaya pencarian. Penelitian merupakan terjemahan dari bahasa Inggris yaitu research, yang berasal dari kata re (kembali) dan to search (mencari). Dengan demikian secara bahasa berarti mencari kembali. Melalui penelitian orang mencari temuan-temuan baru, pengetahuan yang benar yang dapat dipakai untuk menjawab suatu pertanyaan atau menjelaskan dan memecahkan suatu masalah. ${ }^{6}$

\section{Hasil Penelitian dan Pembahasan}

Kartel pada umumnya dipraktikkan oleh asosiasi dagang (trade associations) bersama dengan para anggotanya. Praktik kartel oleh para pelaku usaha dapat tumbuh dan berkembang pada pasar yang berstruktur oligopoli, karena terdapat kemungkinan besar pelaku usaha saling bekerjasama dengan situasi pasar yang hanya terdiri atas beberapa penjual kemudian berkerjasama untuk mengontrol produksi/pemasaran barang/jasa. Berbeda halnya dengan struktur pasar yang kompetitif, jumlah pelaku usaha di dalam suatu pasar terbilang banyak menyebabkan tidak ada hambatan bagi pelaku usaha untuk masuk ke dalam pasar. Hal tersebut membuat setiap pelaku usaha yang ada di dalam pasar tidak akan mampu untuk mengontrol produksi/pemasaran barang/jasa yang berimplikasi pada harga, sesuai dengan keinginannya dan hanya menerima harga yang telah ditentukan oleh pasar serta akan berusaha untuk berproduksi secara maksimal agar dapat mencapai suatu tingkat yang efisien dalam berproduksi. ${ }^{7}$

Pengertian sempit dari kartel adalah sekelompok perusahaan yang seharusnya saling bersaing, tetapi mereka justru menyetujui satu sama lain untuk "menetapkan harga" guna meraih keuntungan monopolistis. Sedangkan dalam

${ }^{6}$ M., "Metodelogi Penelitian Hukum”, Makalah untuk Kuliah Program Magister Hukum Fakultas Hukum Universitas Islam Indonesia, Yogyakarta, 2020.

7 Suhasril dan Muhammad Taufik Makrao, Hukum Larangan Praktik. Monopoli dan Persaingan Usaha Tidak. Sehat di Indonesia, Ghalia Indonesia, Bogor, 2010, hlm. 57. 
pengertian luas, kartel meliputi perjanjian antara para pesaing untuk membagi pasar, mengalokasikan pelanggan, dan menetapkan harga. ${ }^{8}$

Ketentuan kartel diatur dalam Pasal 11 Undang-Undang No. 5 Tahun 1999 menyatakan bahwa:

"Pelaku usaha dilarang membuat perjanjian, dengan pelaku usaha pesaingnya yang bermaksud untuk mempengaruhi harga dengan cara mengatur produksi dan/atau pemasaran suatu barang dan/atau jasa, yang dapat mengakibatkan terjadinya praktek monopoli dan persaingan usaha tidak sehat".

Undang-Undang Antimonopoli dan Persaingan Usaha Tidak Sehat tidak menyediakan penjelasan lebih lanjut mengenai kartel yang diatur dalam Pasal 11.

\section{Unsur-Unsur Kartel}

Kartel adalah kerjasama sejumlah perusahaan yang bersaing untuk mengkoordinasikan kegiatannya sehingga dapat mengendalikan jumlah produksi dan harga suatu barang dan atau jasa untuk memperoleh keuntungannya diatas tingkat keuntungan yang wajar.

Berdasarkan ketentuan Pasal 11 tersebut di atas, maka unsur-unsur yang harus dibuktikan dalam kartel adalah sebagai berikut: ${ }^{9}$

1. Unsur pelaku usaha

Berdasarkan ketentuan Pasal 1 ayat (5) Undang-Undang Antimonopoli dan Persaingan Usaha Tidak Sehat mendefinisi pelaku usaha sebagai berikut:

"Pelaku usaha adalah setiap orang perorangan atau badan usaha, baik yang berbentuk badan hukum atau bukan badan hukum yang didirikan dan berkedudukan atau melakukan kegiatan dalam wilayah hukum Negara Republik Indonesia, baik sendiri maupun bersama-sama melalui perjanjian, menyelenggarakan berbagai kegiatan usaha dalam bidang ekonomi."

2. Unsur perjanjian

Pengertian "perjanjian" dalam Undang-Undang Antimonopoli dan Persaingan Usaha Tidak Sehat diatur dalam Pasal 1 ayat (7) UndangUndangNomor 5 Tahun 1999 sebagai berikut:

"Perjanjian adalah suatu perbuatan satu atau lebih pelaku usaha untuk mengikatkan diri terhadap satu atau lebih usaha lain dengan nama apapun, baik tertulis maupun tidak tertulis."

KPPU mengartikan unsur perjanjian dalam Pasal 11 tentang kartelsebagai perjanjian ataupun kolusi. Salah satu syarat terjadinya kartel adalah harus ada perjanjian atau kolusi antara pelaku usaha. Ada dua bentuk kolusi dalam kartel, yaitu: ${ }^{10}$

\footnotetext{
${ }^{8}$ Anna Maria Tri Anggaraini, "Penggunaan Analisis Ekonomi dalam Mendeteksi Kartel Berdasarkan Hukum Persaingan Usaha”, Jurnal Persaingan Usaha Komisi Pengawas Persaingan Usaha, Edisi 5,2010, hlm. 31.

${ }^{9}$ Peraturan Komisi Pengawas Persaingan Usaha Nomor 4 Tahun 2010 tentang Pedoman Pelaksanaan Pasal 11 Undang-Undang Nomor 5 Tahun 1999 tentang Kartel, hlm. 16-17.

${ }^{10}$ Ibid, hlm. 8.
} 
a. Kolusi eksplisit, dimana para anggota mengkomunikasikan kesepakatan mereka secara langsung yang dapat dibuktikan dengan adanya dokumen perjanjian, data mengenai audit bersama, kepengurusan kartel, kebijakan-kebijakan tertulis, data penjualan dan data-data lainnya.

b. Kolusi diam-diam, dimana pelaku usaha anggota kartel tidak berkomunikasi secara langsung, pertemuan-pertemuan juga diadakan secara rahasia. Biasanya yang dipakai sebagai media adalah asosiasi industri, sehingga pertemuan-pertemuan anggota kartel dikamuflasekan dengan pertemuan-pertemuan yang legal seperti pertemuan asosiasi. Bentuk kolusi yang kedua inilah yang sangat sulit untuk dideteksi oleh para penegak hukum termasuk KPPU.

3. Unsur pelaku usaha pesaingnya

Elemen pelaku usaha pesaingnya terkait erat dengan pasar bersangkutan dimaksudkan untuk mempengaruhi harga.Untuk mencapai tujuan tersebut anggota kartel setuju mengatur produksi dan atau pemasaran suatu barang dan atau jasa.

4. Unsur bermaksud mempengaruhi harga

Sebagaimana dirumuskan dalam Pasal 11 bahwa suatu kartel dimaksudkan untuk mempengaruhi harga.Untuk mencapai tujuan tersebut anggota kartel setuju mengatur produksi dan atau pemasaran suatu barang dan atau jasa.

5. Unsur mengatur produksi dan atau pemasaran

Mengatur produksi artinya adalah menentukan jumlah produksi baik bagi kartel secara keseluruhan maupun bagi setiap anggota. Hal ini bisa lebih besar atau lebih kecil dari kapasitas produksi perusahaan atau permintaan akan barang atau jasa yang bersangkutan. Sedangkan mengatur pemasaran berarti mengatur jumlah yang akan dijual dan atau wilayah dimana para anggota menjual produksinya.

6. Unsur barang

Barang menurut Pasal 1 angka 16 adalah setiap benda baik berwujud maupun tidak berwujud, baik bergerak maupun tidak bergerak, yang dapat diperdagangkan, dipakai, dipergunakan atau dimanfaatkan oleh konsumen atau pelaku usaha.

7. Unsur jasa

Jasa menurut Pasal 1 angka 17 adalah setiap layanan yang berbentuk pekerjaan atau prestasi yang diperdagangkan dalam masyarakat untuk dimanfaatkan oleh konsumen atau pelaku usaha.

8. Unsur dapat mengakibatkan terjadinya praktek monopoli Praktek monopoli menurut Pasal 1 angka 2 adalah pemusatan kekuatan ekonomi oleh satu atau lebih pelaku usaha yang mengakibatkan dikuasainya produksi dan atau pemasaran atas barang dan atau jasa tertentu sehingga menimbulkan persaingan usaha tidak sehat. Dengan kartel, maka produksi dan pemasaran atas barang dan atau jasa akan 
dikuasai oleh anggota kartel. Karena tujuan akhir dari kartel adalah untuk mendapatkan keuntungan yang besar bagi anggota kartel, maka hal ini akan menyebabkan kerugian bagi kepentingan umum.

9. Unsur dapat mengakibatkan persaingan usaha tidak sehat

Pasal 1 angka 6 menyatakan bahwa persaingan usaha tidak sehat adalah persaingan antar pelaku usaha dalam menjalankan produksi dan atau pemasaran barang dan atau jasa yang dilakukan dengan cara tidak jujur atau melawan hukum. Kartel adalah suatu kolusi atau kolaborasi dari para pelaku usaha, oleh karena itu segala manfaat kartel hanya ditujukan untuk kepentingan para anggotanya saja, sehingga tindakantindakan mereka ini dilakukan secara tidak sehat dan tidak jujur.Dalam hal ini misalnya dengan mengurangi produksi atau melawan hukum atau menghambat persaingan usaha, misalnya dengan penetapan harga atau pembagian wilayah.

Unsur "yang dapat mengakibatkan terjadinya praktek monopoli dan persaingan usaha tidak sehat" merupakan indikasi bahwa Pasal 11 mengadopsi prinsip "rule of reason". Dengan demikian KPPU harus dapat membuktikan bahwa alasan-alasan dari pelaku usaha tersebut tidak dapat diterima (unreasonable). (lihat Pedoman Pasal 11)

Alasan-alasan dari pelaku usaha yang melakukan perbuatan yang menghambat perdagangan dapat dinyatakan sebagai sesuatu yang tidak dapat diterima (unreasonable restraint) apabila:

a. Kegiatan para pelaku usaha menunjukkan tanda-tanda adanya pengurangan produksi atau naiknya harga. Apabila terdapat tanda-tanda tersebut, maka perlu diperiksa lebih lanjut;

b. Apakah kegiatan para pelaku usaha bersifat naked (langsung) atau ancillary (tambahan), kalau kegiatan tersebut bersifat naked, maka merupakan perbuatan yang melawan hukum. Sedangkan kalau ancillary, maka diperkenankan;

c. Para pelaku usaha mempunyai market power, maka terdapat kemungkinan mereka menyalahgunakan kekuatan tersebut;

d. Apakah terdapat hambatan masuk ke pasar yang tinggi. Walaupun para pelaku usaha mempunyai market power, akan tetapi kalau tidak ada hambatan masuk ke pasar yang berarti, maka akan mudah bagi pelaku usaha baru untuk masuk ke pasar;

e. Perbuatan para pelaku usaha apakah menciptakan efisiensi yang substansial dan menciptakan peningkatan kualitas produk atau servis atau adanya inovasi. Apabila alasan-alasan ini tidak terbukti, maka perbuatan tersebut adalah ilegal;

f. Perbuatan-perbuatan para pelaku usaha tersebut memang diperlukan untuk mencapai efisiensi dan inovasi. Artinya harus dibuktikan apakah perbuatan para pelaku usaha tersebut adalah alternatif terbaik untuk mencapai tujuan tersebut; 
g. Perlu dilakukan adanya "balancing test" artinya perlu diukur keuntungankeuntungan yang diperoleh dari perbuatan para pelaku usaha dibandingan dengan akibat-akibat negatifnya. Apabila keuntungan yang diperoleh lebih besar dari kerugiannya, maka perbuatan tersebut dibenarkan.

\section{Indikator Awal Terjadinya Kartel}

Upaya dalam memenuhi persyaratan bukti awal yang cukup, KPPU dapat memeriksa beberapa indikator awal yang dapat disimpulkan sebagai faktor pendorong terbentuknya kartel.Secara teori, ada beberapa faktor yang dapat mendorong atau memfasilitasi terjadinya kartel baik faktor struktural maupun perilaku.Sebagian atau seluruh faktor ini dapat digunakan KPPU sebagai indikator awal dalam melakukan identifikasi eksistensi sebuah kartel pada sektor bisnis tertentu. Beberapa diantara faktor-faktor tersebut akan diuraikan di bawah ini.

\section{Faktor struktural (Structural Methodology): ${ }^{11}$}

\section{a. Tingkat konsentrasi dan jumlah perusahaan}

Secara prinsip, kartel akan lebih mudah jika jumlah perusahaan tidak banyak. Dalam hal ini indikator tingkat konsentrasi pasar seperti misalnya CR4 (jumlah pangsa pasar empat perusahaan terbesar) dan HHI (HerfindahlHirschman Index) merupakan indikator yang baik untuk melihat apakah secara struktur, pasar tertentu mendorong eksistensi kartel.

\section{b. Ukuran perusahaan}

Kartel akan lebih mudah terbentuk jika pendiri atau pelopornya adalah beberapa perusahaan yang mempunyai ukuran setara. Dengan demikian pembagian kuota produksi atau tingkat harga yang disepakati dapat dicapai dengan lebih mudah dikarenakan kapasitas produksi dan tingkat biaya produksi semua perusahaan tersebut tidak berbeda jauh.

\section{c. Homogenitas produk}

Produk yang homogen, baik berupa barang atau jasa, menyebabkan preferensi konsumen terhadap seluruh produk tidak berbeda jauh.Hal ini menjadikan persaingan harga sebagai satu-satunya variabel persaingan yang efektif. Dengan demikian dorongan para pengusaha untuk bersepakat membentuk kartel akan semakin kuat untuk menghindari perang harga yang menghancurkan tingkat laba mereka. KPPU dapat melakukan survey kepada pelanggan produk tertentu untuk mengetahui tingkat preferensi pelanggan dan menyimpulkan tingkat homogenitas produk tersebut. 


\section{d. Kontak multi-pasar}

Pemasaran yang luas dari suatu produk memungkinkan terjadinya kontak multi-pasar dengan pesaingnya yang juga mempunyai sasaran pasar yang luas.Multi-pasar dapat diartikan persaingan di beberapa area pasar atau di beberapa segmen pasar.Kontak yang berkali-kali ini dapat mendorong para pengusaha yang seharusnya bersaing untuk melakukan kolaborasi, misalnya dengan alokasi wilayah atau harga. Selain itu, tidak ada insentif bagi para pelaku usaha tersebut untuk tidak ikut dalam kartel karena adanya kekhawatiran "tindakan balasan" dari anggota kartel di seluruh area atau segmen pasar sasaran.

\section{e. Persediaan dan kapasitas produksi}

Persediaan yang berlebihan di pasar menunjukkan telah terjadi kelebihan penawaran (overstock).Begitu pula kapasitas terpasang yang berada di atas permintaan menunjukkan kemampuan pasokan berada di atas tingkat permintaan saat ini. Untuk mencegah persaingan harga yang merugikan, pada kondisi ini para pelaku usaha akan mudah terperangkap dalam perilaku kartel harga, yaitu menyepakati harga tertentu atau harga minimum.

Selain itu, kelebihan pasokan ini mencegah anggota kartel untuk menyimpang mengingat pasokan yang tersedia cukup banyak untuk "menghukum" mereka yang menyimpang dengan membanjiri pasar sehingga harga akan jatuh dan pengusaha akan kesulitan memasarkan produknya. Data akan persediaan dan kapasitas produksi dapat dijadikan indikator awal untuk mengindentifikasi kartel.

\section{f. Keterkaitan kepemilikan}

Keterkaitan kepemilikan baik minoritas terlebih lagi mayoritas mendorong pengusaha untuk mengoptimalkan laba melalui keselarasan perilaku di antara perusahaan yang mereka kendalikan.Pemegang saham dua atau lebih perusahaan yang semestinya bersaing cenderung memanfaatkan kepemilikan silang ini untuk memperkuat kartel dalam rangka mengoptimalkan keuntungan. Berbagai pengaturan kartel akan berlangsung lebih mudah dengan adanya kepemilikan silang ini.

\section{g. Kemudahan masuk pasar}

Tingginya entry barrier sebagai hambatan bagi perusahaan baru untuk masuk pasar akan memperkuat keberadaan suatu kartel. Peluang pendatang baru untuk mengisi kekosongan pasar akibat harga kartel yang tinggi agak tertutup. Dengan demikian kartel akan dapat bertahan dari persaingan pendatang baru.

\section{h. Karakter permintaan: keteraturan, elastisitas dan perubahan}

Permintaan yang teratur dan inelastis dengan pertumbuhan yang stabil akan memfasilitasi berdirinya kartel. Hal ini terjadi karena adanya kemudahan 
bagi para peserta kartel untuk memprediksi dan menghitung tingkat produksi serta tingkat harga yang dapat mengoptimalkan keuntungan mereka.

Sebaliknya jika permintaan sangat fluktuatif, elastis dan tidak teratur akan menyulitkan terbentuknya kartel. Para peserta akan berebut order pada saat permintaan tinggi dan terpaksa bersaing menurunkan harga mengingat sifat permintaan yang elastis. KPPU dapat mengukur karakter permintaan ini baik melalui survey dan penelitian pasar maupun informasi dari para produsen.

\section{i. Kekuatan tawar pembeli (buyer power)}

Pembeli dengan posisi tawar yang kuat akan mampu melemahkan dan akhirnya membubarkan kartel. Dengan posisi ini, pembeli akan mudah mencari penjual yang mau memasok dengan harga rendah, yang berarti mendorong penjual untuk tidak mematuhi harga kesepakatan kartel. Pada akhirnya kartel.

\section{Faktor Perilaku(Behavioral Methods)}

\section{a. Transparansi dan Pertukaran Informasi}

Kartel akan mudah terbentuk jika para pelaku usaha terbiasa dengan pertukaran informasi dan transparansi diantara mereka. Peran asosiasi yang kuat seringkali terlihat sebagai media pertukaran ini.Data produksi dan harga jual yang dikirimkan ke asosiasi secara periodik dapat digunakan sebagai sarana pengendalian kepatuhan terhadap kesepakatan kartel. Terlebih lagi jika ditemukan terjadinya pertukaran informasi harga dan data produksi tanpa melalui asosiasi, yang mana akan terlihat janggal jika sesama pelaku usaha saling memberikan harga dan data produksi diantara mereka tanpa tujuan tertentu sehingga kecurigaan akan eksistensi kartel akan menguat. ${ }^{12}$

\section{b. Peraturan Harga dan Kontrak}

Beberapa perilaku pengaturan harga dan kontrak dapat memperkuat dugaan adanya kartel di suatu industri. Misalnya kebijakan one price policy dimana kesamaan harga di berbagai daerah akan menjadi alat monitoring yang efektif antar anggota kartel terhadap kesepakatan harga kartel. Begitu pula keharusan memperoleh harga yang sama seperti klausul MFN (Most Favoured Nations) atau meet the competition dalam suatu kontrak akan memudahkan kontrol terhadap anggota kartel yang menyimpang. Oleh karena itu, walaupun bukan merupakan syarat perlu maupun cukup dalam mengidentifikasi kartel, perilaku pengaturan harga dan kontrak patut dicermati oleh KPPU sebagai bagian upaya identifikasi eksistensi kartel.

12 Ibid, hlm. 22-23. 
Secara umum, untuk mendeteksi adanya kartel dapat dilakukan menggunakan dua metode pendekatan, yakni Metode Reaktif dan Metode Proaktif. Metode Reaktif adalah metode yang didasarkan pada beberapa kondisi eksternal yang terjadi sebelum otoritas persaingan menyadari beberapa kemungkinan atas issue kartel dan memulai suatu investigasi. Dalam hal terdapat kartel yang dilakukan secara tersembunyi, maka sangat efektif jika menggunakan informasi orang dalam (inside information)untuk mendeteksi kartel.Informasi orang dalam dapat berasal dari perusahaan (pelaku kartel) atau para individu yang mengetahui kartel tersebut, kemudian melaporkannya kepada otoritas persaingan. ${ }^{13}$

Metode lainnya adalah Metode pendekatan Proaktif, yakni metode pendekatan yang diinisiasi oleh otoritas persaingan untuk mendeteksi kartel, dan tidak berkaitan dengan peristiwa eksternal. Adapun bentuk penggunaan Metode Proaktif adalah analisis/studi tentang ekonomi atau analisis/studi tentang pasar, penelusuran melalui media, monitoring kegiatan industri atau sector tertentu, serta pertukaran pengalaman maupun best practices dari otoritas persaingan lainnya. ${ }^{14}$

\section{Bukti Tidak Langsung (Indirect Evidence)}

Terdapat dua tipe pembuktian tidak langsung, meliputi bukti komunikasi dan bukti ekonomi.Dari kedua bukti tersebut, bukti komunikasi atau fasilitasi lebih penting dibandingkan bukti ekonomi. Bukti komunikasi adalah bukti dimana pelaku kartel bertemu melakukan komunikasi akan tetapi tidak menjelaskan substansi komunikasi tersebut. ${ }^{15}$ Hal ini mencakup, catatan percakapan telepon antara para peserta tersangka kartel, namun tidak termasuk substansi yang sebenarnya dari komunikasi tersebut.Selanjutnya, perjalanan ke tujuan melalui rute umum atau partisipasi rapat. Bukti komunikasi lainnya menunjukkan risalah rapat yang mengindikasikan pemanfaatan harga, permintaan atau kapasitas, dokumen internal yang membuktikan pengetahuan atau pemahaman tentang strategi harga pesaing, seperti harga di masa depan. ${ }^{16}$

Bukti ekonomi dapat membantu untuk mengidentifikasi pasar akan terjadinya kartel. Menurut Andi Fahmi, analisis ekonomi dalam penentuan motif dan dampak tersebut terbagi atas: ${ }^{17}$

${ }^{13}$ Anggraini Anna Maria, Loc. Cit., hlm. 35.

${ }^{14}$ Ibid., hlm. 35.

${ }^{15}$ Ibid.

${ }^{16}$ Siti Anisah, "Penyelesaian Sengketa KPPU dan Pembuktian Tidak Langsung pada Kasus Kartel", Makalah dalam Diskusi Akademik KPPU RI dengan Narasumber Hukum Persaingan Usaha Fakutas Hukum Universitas Islam Indonesia, Yogyakarta, 2013, hlm. 6.

17"Indirect Evidence: Kontroversi dan Analisanya dalam Hukum Ekonomi", terdapat dalam, http://www.kppu.go.id/id/2012/03/indirect-evidence-kontroversi-dan-analisanya-dalam-hukum-ekonomi, diakses tanggal 28 Januari 2016. 
a. analisis insentif yang bertujuan untuk melihat apakah suatu perusahaan tertarik atau termotivasi untuk melakukan suatu perilaku yang bersifat strategi,

b. analisis kemampuan yang bertujuan untuk melihat apakah sebuah perusahaan mampu untuk melakukan perilaku strategis yang efektif

c. analisis untung rugi yang bertujuan untuk melihat apakah dampak negatif suatu perilaku strategis lebih besar dari dampak positifnya.

Ketiga analisis ini tidak harus digunakan sekaligus dalam pembuktian kasus.Contohnya, tidak semua kasus membutuhkan analisa untung rugi. Selain ketiga analisis tersebut, pembuktian kartel juga harus memperhatikan apa yang disebut sebagai Plus Factor. Plus factor ini diantaranya terdiri atas:

a. analisa terhadap rasionalisasi penetapan harga,

b. analisa struktur pasar,

c. analisa data kinerja dan

d. analisa penggunaan fasilitas kolusi.

Dalam upaya pembuktian, tidak seluruh alat analisa tambahan (plus factor) di atas harus dipenuhi.Komisi dapat memutuskan bahwa alat analisa tertentu sudah cukup digunakan untuk membuktikan pelanggaran UndangUndangAntimonopoli dan Persaingan Usaha Tidak Sehat.Andi Fahmi, mengatakan bahwa analisis ekonomi dimungkinkan dalam pembuktian kartel. Analisis itu sendiri berguna dalam menentukan motif dan atau memprediksi dampak dari suatu perilaku (behavior).

Bukti-bukti lainnya yang dapat diandalkan oleh Komisi adalah termasuk penjelasan lisan yang dibuat oleh perusahaan dan direkam pada saat investigasi berlangsung. Laporan mendetail tentang rapat kartel kemungkinan dipersiapkan untuk para petinggi perusahaan yang dibubuhi tulisan penanda "Top secret-No copy to file", sementara salinan dari dokumen tersebut disimpan oleh penulisnya. Dokumen-dokumen semacam itu memiliki nilai kebenaran pembuktian yang lebih tinggi daripada sekedar penjelasan lisan yang dilakukan usai masa investigasi. ${ }^{18}$

Dalam kasus dugaan kartel kontainer di pelabuhan Belawan Medanyang digunakan KPPU sebagai indirect evidence ialah hasil analisis terhadap hasil pengolahan data yang mencerminkan terjadinya super normal profit yang terjadi bukan karena peningkatan efisiensi dan produktivitas perusahaan. Tim Pemeriksa melihat trend yang sama atas pergerakan tarif angkutan kontainer di antara Terlapor untuk masing-masing jarak. Tim investigasor KPPU juga melakukan uji korelasi terhadap penetapan harga tersebuttersebut. Maka KPPU berpandangan bahwa

${ }^{18}$ Siti Anisah, Loc. Cit. 
meskipun tidak ada kesepakatan tertulis secara langsung diantara para Terlapor dalam menetapkan besaran tarif kontainer namun bukti-bukti lainnya seperti halnya surat edaran organda maka berdasarkan analisis pergerakan maka penetapan tarif angkutan kontainer memangada, baik analisis grafik, tabel uji korelasi dan uji varians menunjukkan adanya trend dan variasi yang mengarahkan pada suatu kesimpulan bahwa telah terjadi kesepakatan penetapan penetapan tarif angkutan kontainerdiantara para terlapor/ pelaku usaha.

Dalam Investigasinya KPPU melihat terdapat perjanjian penetapan tarif angkutan kontainer ukuran 20", 40" dan 2×20" di 12 rute dari dan menuju Pelabuhan Belawan tahun 2012 yang ditandatangani oleh satu atau lebih pelaku usaha, yang saling mengikatkan diri terhadap satu atau lebih pelaku usaha lain, untuk menetapkan tarif angkutan kontainer di 12 rute dari dan menuju Pelabuhan Belawan pada tahun 2011 dan 2012 yang disepakati oleh Terlapor I, II, III, IV, V, VI, VII, VIII, IX, X, XI, XII, XIII, XIV sebagaimana tertuang dalam bersama antara Organda Belawan dengan Gafeksi Sumut dengan No.010/DPU.ORG/KB/II/2012 dan atau No.001/KPTS/DPW/II/2012 tentang tarif angkutan peti kemas/barang di jalan, dari dan ke Pelabuhan Belawan yang ditandatangani pada 08 Februari 2012.

Dalam pertimbangannya Majelis Komisi menjelaskan bahwa Perjanjian sebagaimana dituangkan pada Pasal 1 angka 7 UU No. 5/1999 berbunyi: "Perjanjian adalah suatu perbuatan satu atau lebih pelaku usaha untuk mengikatkan diri terhadap satu atau lebih pelaku usaha lain dengan nama apapun, baik tertulis maupun tidak tertulis. Perjanjian sebagaimana Pasal 1313 Kitab Undang-Undang Hukum Perdata berbunyi: "Suatu perjanjian adalah suatu perbuatan dimana satu atau lebih mengikatkan diri terhadap satu orang lain atau lebih."

Definisi perjanjian pada Pasal 1313 KUHPerdata Subekti berpendapat bahwa suatu perjanjian merupakan suatu peristiwa di mana seseorang berjanji kepada orang lain, atau di mana dua orang saling berjanji untuk melaksanakan sesuatu hal ${ }^{19}$, kemudian R. Setiawan, menyebutkan bahwa perjanjian ialah suatu perbuatan hukum di mana satu orang atau lebih mengikatkan dirinya atau saling mengikatkan dirinya terhadap satu orang atau lebih. ${ }^{20}$

Dalam Pasal 1 angka 7 UU No. 5 Tahun 1999 menyebutkan "Perjanjian adalah suatu perbuatan satu atau lebih pelaku usaha untuk mengikatkan diri terhadap satu atau lebih pelaku usaha lain dengan nama apapun, baik tertulis maupun tidak tertulis".

Pengertian tersebut tidak jauh berbeda dengan pengertian perjanjian dalam Kamus Besar Bahasa Indonesia yang menyatakan bahwa perjanjian adalah persetujuan (tertulis atau dengan lisan) yang dibuat oleh dua pihak atau lebih,

${ }^{19}$ Subekti, Op. Cit., hlm. 20.

${ }^{20}$ R. Setiawan, Op. Cit., hlm. 49. 
masing-masing bersepakat akan menaati apa yang tersebut dalam persetujuan itu. Sedangkan dalam Black's Law Dictionary yang dimaksud dengan perjanjian atau kontrak adalah "an agreement between two or more persons which creates an obligation to do or not to do a particular thing". ${ }^{21}$

Meskipun sulit untuk dibuktikan, perjanjian lisan secara hukum sudah dapat dianggap perjanjian yang sah dan sempurna. Unsur adanya perjanjian tetap disyaratkan, dimana perjanjian lisan dianggap sudah cukup memadai untuk menyeret si pelaku untuk bertanggung jawab secara hukum.22Jika dibandingkan dengan definisi yang diberikan dalam Pasal 1313 KUHPerdata yang merumuskan perjanjian sebagai suatu perbuatan dengan mana satu orang atau lebih mengikatkan dirinya terhadap satu orang atau lebih, maka dapat dilihat bahwa pada prinsipnya secara esensi tidak ada suatu perbedaan yang berarti, hanya saja dalam Undang -Undang No. 5 Tahun 1999 definisi yang telah diberikan secara tegas menyebutkan pelaku usaha sebagai subjek hukumnya, yaitu setiap orang perseorangan atau badan usaha, baik yang berbentuk badan hukum atau bukan badan hukum yang didirikan dan berkedudukan atau melakukan kegiatan dalam wilayah hukum negara Republik Indonesia, baik sendiri maupun bersama-sama melalui perjanjian, menyelanggarakan berbagai usaha dalam bidang ekonomi. ${ }^{23}$

Perjanjian yang dirumuskan dalam Pasal 1 angka 7 tersebut adalah perjanjian sepihak. Namun, tidak berarti hanya perjanjian sepihak yang terkena Undang-Undang No. 5 Tahun 1999. Harus dipahami bahwa perjanjian sepihak saja sudah dapat terkena Undang-Undang No. 5 Tahun 1999. Kalau perjanjian sepihak tidak dilarang, keadaan ini akan disalahgunakan, sehingga akan terjadi perjanjian sepihak yang ditaati oleh pihak-pihak yang sebenarnya tidak terikat yang akhirnya merusak persaingan. Hal ini bisa diatasi dengan menambah suatu ketentuan lain seperti persekongkolan. Dengan ini, walaupun pasal perjanjian tidak bisa diberlakukan, mereka akan terkena ketentuan terakhir. ${ }^{24}$

\section{Penutup}

Konsep pembuktian yang digunakan dalam menetapkan perjanjian penetapan harga dalam Pasal 5 Undang-Undang Nomor 5 Tahun 1999, menurut hukum persaingan usaha ialah dengan membuktikan setiap unsur dalam Pasal 5, meliputi

${ }^{21}$ Hermansyah, Op. Cit., hlm. 24.

${ }^{22}$ Munir Fuady, Hukum Anti Monopoli Menyongsong Era Persaingan Sehat, Citra Aditya Bakti, Bandung, 2003 hlm. 51.

23Ahmad Yani dan Gunawan Widjaja, Seri Hukum Bisnis Anti Monopoli, RajaGrafindo Persada Jakarta, 1999, hlm. 21.

${ }^{24}$ Rahmadi Usman, Op. Cit., hlm. 38. 
pelaku usaha, membuat perjanjian, pelaku usahapesaing, menetapkan harga atas suatu barang dan/atau jasa yang harusdibayar oleh konsumen/pelanggan dan pasar bersangkutan yang sama. Pembuktiannya lebih kepada pembuktian secara materiil tanpa mengesampingkan bukti tertulis sebagai pembuktian formal. Pendekatan hukum yang digunakan ialah per-se illegal, yaitu suatu perilaku bisnis tertentu yang dipandang sebagai sebuah pelanggaran undang-undang, dengan mengadakan perjanjian penetapan harga diantara pelaku usaha. Berdasarkan bunyi ketentuan undang-undang sudah sepatutnya pendekatan dalam pembuktian Pasal 5 ini diterapkan secara per-se illegal, namun dalam perkembangannya rule of reason menjadi alternatif pendekatan yang digunakan untuk membuktikan ketentuan pasal tersebut. Beberapa ciri dalam putusan KPPU memiliki kesamaan dengan bentuk aturan dalam hukum acara pidana sebagaimana yang diatur dalam KUHAP, yang meliputi keterangan saksi, keterangan ahli, surat/dokumen, petunjuk, dan keterangan terdakwa. Bahwa dalam prakteknya, penggunaan Pasal 5 tidak berdiri sendiri/tunggal, melainkan disandingkan juga dengan pasal-pasal yang lain karena motif perbuatan pelaku usaha, dengan kompleksitas kasus berbeda-berbeda dapat mengenakan pasal lain, misalnya Pasal 9, Pasal 11, Pasal 17 dan Pasal 19. Di mana perbuatan pelaku usaha sebagai terlapor tersebut memiliki tendensi kearah perbuatan yang dilarang oleh undang-undang, dalam hal ini Undang-Undang Nomor 5 Tahun 1999.Putusan KPPU Perkara Nomor: 06/KPPU-I/2013 tentang Kasus kartel Tarif Angkutan Kontainer Pelabuhan Belawan di Indonesia dalam proses pembuktiannya menggunakan alat bukti tidak langsung sebagai petunjuk untuk menyempurnakan pembuktian dalam sidang Majelis Komisi. Dasar pertimbangan Pengadilan Negeri dan dan Mahkamah Agung ini adalah, Majelis Hakim meyakini bahwa indirect evidence adalah alat bukti yang tidak di ataur dalam Hukum Acara di Indonesia. Namun, dalam perkembangannya pada Tahun 2011 Mahkamah Agung mulai mengakui indirect evidence sebagai bukti tidak langsung dalam Hukum acara di Indonesia melalui Putusan Mahkamah Agung No. 906 K/Pdt.Sus/2010 dalam kasus persekongkolan tender. Putusan inilah yang kemudian hari dapat dijadikan dasar hukum untuk menangani kasus monopoli dan persaingan usaha tidak sehat khususnya dalam kasus kartel di Indonesia.

\section{Daftar Pustaka}

\section{Buku}

Fuady, Munir, Hukum Anti Monopoli Menyongsong Era Persaingan Sehat, Citra Aditya Bakti, Bandung, 2003.

Kamal, Rokan Mustafa, Hukum Persaingan Usaha: Teori dan Praktiknya di Indonesia, RajaGrafindo Persada, Jakarta, 2012. 
Lubis, Andi Fahmi, dkk., Hukum Persaingan Usaha: Antara Teks E Konteks, KPPU Republik Indonesia, Jakarta, 2009.

Suhasril dan Muhammad Taufik Makrao, Hukum Larangan Praktik Monopoli dan Persaingan Usaha Tidak Sehat di Indonesia, Ghalia Indonesia, Bogor, 2010.

Yani, Ahmad dan Gunawan Widjaja, Seri Hukum Bisnis Anti Monopoli, RajaGrafindo Persada, Jakarta, 1999.

\section{Jurnal}

Anggaraini, Anna Maria Tri, "Penggunaan Analisis Ekonomi dalam Mendeteksi Kartel Berdasarkan Hukum Persaingan Usaha" Jurnal Persaingan Usaha Komisi Pengawas Persaingan Usaha, Edisi 5, Komisi Pengawas Persaingan Usaha Republik Indonesia, Jakarta, 2010.

\section{Makalah}

Anisah, Siti, "Penyelesaian Sengketa KPPU dan Pembuktian Tidak Langsung pada Kasus Kartel" Makalahdalam Diskusi Akademik KPPU RI dengan Narasumber Hukum Persaingan Usaha Fakutas Hukum Universitas Islam Indonesia, Yogyakarta, 2013.

Syamsuddin, M., "Metodelogi Penelitian Hukum”, Makalah untuk Kuliah Program Magister Hukum Fakultas Hukum Universitas Islam Indonesia, Yogyakarta, 2020.

\section{Internet}

Hasim Purba, "Tinjauan terhadap Holding Company, Trust, Cartel dan Concern",http:/ / repository.usu.ac.id/handle/123456789/1507, diakses tanggal 22 Januari 2016.

"Kartel Pengusaha Angkutan di Belawan", http://medan.kppu.go.id/ 2014/11/kartel-pengusaha-angkutan-di-belawan/, diakses tanggal 28 Januari 2016.

\section{Peraturan Perundang-Undangan}

Undang-Undang No. 5 Tahun 1999 tentang Monopoli dan Persaingan Usaha Tidak Sehat.

Peraturan Komisi Pengawas Persaingan Usaha Nomor 4 Tahun 2010 tentang Pedoman Pelaksanaan Pasal 11 Undang-Undang Nomor 5 Tahun 1999 tentang Kartel. 